\title{
Government Expending, Real Interest Rate, and Economic Growth in Nepal
}

\author{
Arbind Chaudhary ${ }^{1}$ \\ Mahesh Acharya ${ }^{2}$
}

\begin{abstract}
This paper aims to obtain a linear and causal relationship between government expenditure and real interest rate to the economic growth of Nepal for 1975-2015. The applied ARDL cointegration technique yields a long-run association among the variables. Furthermore, the variables: government expenditure, real interest rate, and other control variablesaverage rainfall and trade openness - are established as long-run elements to the national income. The real interest rate has a substitution effect on the Nepalese household sector, hence it hurts the real income. However, trade openness, public expenditure, and average rainfall are recorded as the short-run determinants. Similarly, the study also explores the existence of a bidirectional causal relationship between government expenditure and real income.
\end{abstract}

Key Words: Government expenditure, Substitution effect, Bound testing, Stability test, Bi-directional causality

\section{Introduction}

Economists always have different arguments, whether public spending brings a positive or negative effect on the economy. The classical economists are supporters of laissez-faire, however, Keynesian economists are on the behalf of strong government intervention. According to the classist government, intervention creates nothing but disturbances on the automatic mechanism of the market economy. Hence, government expenditure and revenue programs as 'necessary evils' (Romanus, 2014). They argued in favor of a balanced budget. In a fully employed situation, if the government increases public expenditure without increasing its revenues, it will lead to inflation. In this case, the state must borrow, and then this borrowing must be confined to the financing of productive enterprises. Otherwise, borrowing will be meaningful if it is used in productive sectors (Weber, 1947). However, Keynes (1936) has opposed the idea of classical theory and says government expenditure roles are different according to the situation of the economy, for instance, the government should adopt a surplus budget at the time of Boom.

1 Mr. Chaudhary is a research associate at Centre for Social Inclusion and Federalism, Lalitpur, Nepal.

2 Mr. Acharya is a freelance researcher in the field of economics. 
On the other hand, during the depression, there is a decrease in effective demand. Hence, the government should increase its expenditure and spend more on public works to uplift economic growth. In the extended Solow (1956) and Swan (1956) model, however, human capital is an important input to growth (Mankiw et.al., 1992). In the endogenous models, public policies can affect both human capital formation and technological progress, and therefore public policies can also influence economic growth (Bleaney et al., 2000). Recent literature on endogenous growth theory predicts that fiscal policy changes can affect the long-term growth rate by influencing the determinants of growth-physical and human capital, technological changes, employment, and savings (Hjerppe, 2006).

Peacock and Wiseman (1961) analyze the time pattern of public expenditure. The main argument is that public expenditure does not increase smoothly and continuously but in a jerky pattern or step-like fashion. Musgrave (1969), and Rostow (1971) have done a study about the public expenditure and found that in the early stages of economic growth and development, public sector investment as a proportion of the total investment of the economy is very high. At this level, the public sector provides social infrastructure, such as roads, transportation systems, sanitation systems, law and order, health and education, and investment in human capital. The public sector is necessary to gear up the economy for take-off into the middle stages of economic and social development. In the middle stages of growth, the government continues to supply investment goods but complementing the private sector investment.

Similarly, another argument comes under the Colin Clark Hypothesis or Central Limit Hypothesis. To support this statement, Clark (1954) argues that when the government share of aggregate economic activity reaches the critical limit of twenty-five percent, the income earners are also affected by reduced incentives due to high tax incidence that their productivity suffers. Also Clark studies the relationship between public expenditure and inflation is only partial. Inflation so far as it brought about spending relates to the equilibrium situation between supply and demand for scarce resources, i.e., between the capacity output of the economy and the aggregate spending for such output.

Baumol (1986) clarifies the productivity differentials of the private and public sectors. When the economy is not automatically stabilized, then expansion in public expenditure is made. However, there is a productivity lag due to Technical and Institutional barriers in the public sector in comparison to the private sector. That results in a low growth of income. On the flip side, Richard W. Rahn has developed The Rahn Curve; it suggests that there is an optimal level of government spending which maximizes the rate of economic growth. Initially, higher government spending helps to improve economic performance. But, after exceeding a certain amount of government spending, government taxes and intervention diminishes economic performance and growth rates. This threshold is between 15-25 percent of the GDP (Rahn \& Fox, 1996). Public expenditure is for protecting the citizens and for promoting their economic and social welfare. Public expenditure is one of the instruments through which the government influences economic events (Goode, 1984). Moreover, government spending is divided into two categories: current expenditure, and development expenditure. Current expenditure is the regular government expenditure that is useful to run the day to day administration of the country. The development expenditure is one that 
is useful for the infrastructure building, providing different services in education, health, agriculture, etc. (Sharma, 1999).

On another side, the real interest rate also plays a crucial role to augment the GDP of the economy. It has a dual effect: the income effect and the substitution effect. Income effect shows less saving at a higher interest rate for lower-income earners in society because most of the part goes into consumption and higher interest even does not influence them. To add, the substitution effect explores the reduction of present consumption due to a higher interest rate for future income-return interest form deposit (Sapiro, 2001). These two effects directly hit to consumption demand. On the flip side, the interest rate also directly relates to private investment expenditure and takes inverse relation with it (Ahuja, 2011). Thus, both factors - government expenditure and real interest play a crucial role or increasing the GDP size. Increasing GDP size may also impact on government expenditure. Therefore, in the case of Nepal, it raises a couple of serious questions: what is the linear relationship between government expenditure and real interest rate to the economic growth of Nepal and, does there exist a causal relationship between government expenditure and real income?

Further organization of this paper is extended by the literature review. It encompasses international research review and national review. The reviews guide the paper in a proper direction and help to quest a sharp research gap at the end. The third section is data and research methods. This section reveals the nature and sources of raw data, description of the variables, rationale of selecting those variables, and proper econometrical tools and techniques. The fourth section is the result and discussion of the raised questions, and the last section covers a cohesive conclusion and policy implications.

\section{Literature Review}

Desmond et al., (2012) carry out the linear relationship between public expenditure and economic growth in Nigeria. Utilizing multiple regression models, it is observed that capital expenditure on transfers has an insignificant effect on growth. However, capital and recurrent expenditures on social and community services and recurrent expenditure on transfers have a significant and positive effect on economic growth. Kweka and Morrissey (2000) study the relationship between government spending and economic growth in Tanzania between 1965-1996. The model observes that physical investment has a negative effect, but, consumption expenditure has a positive effect on economic growth. Udoka and Roland (2013) explore the effect of interest rate variability on the economic growth of Nigeria. The result shows an inverse relationship existed between the interest rate and economic growth in Nigeria. Similarly, Saymeh and Orabi (2013) and Hidayat and Suman (2012) reveal that interest rates have a negative relationship with economic growth in Jordan and Indonesia respectively.

Alshahrani and Alsadiq (2014) find the long-run association between public investment and economic growth in Saudi Arabia for 1969-2010, employing Johansson co-integration 
technique. Similarly, Alexiou (2009) explores the effect of government spending on the economic growth of Eastern Europe. The test reveals that capital formation, development assistance, private investment, and trade openness are significant factors for the growth of those countries. Kosimbei, Maingiand, and Thuku (2013) find out the impact of the sectoral government expenditure such as expenditure on health, education, defense, infrastructure, and public order and security on the economic growth in Kenya from 1964-2011. The study showed that government expenditure on education is positively related to economic growth it does not spur any significant change to growth but the expenditure on health, public and private investment has a significant effect on the economic growth of the country. Oyinlola and Akinnibosun (2013) trace out Wagner law in Nigeria during the period 1970-2007. Employing the Gregory-Hansen structural break co-integration technique, the results confirm the presence of Wagner law. Also, there is a break in 1993 in which the political crisis that engulfed the nation was accountable. Similarly, Rahman (2012) establishes similar results. Mulamba (2009) investigates the validity of Wagner's law and the Keynesian perspective of a long-run relationship and causality between government expenditure and economic growth in SADC countries from 1998 to 2004. Panel co-integration, namely, the Pedroniel cointegration test and Kao panel cointegration test show that the long-run relationship exists between government expenditure and the economic growth in the SADC countries. Also, the economic growth rate Granger causes government expenditure in both the short run and long run which consistence of Wagner's law than the Keynesian stance. Yilgor (2009) finds similar results for Turkey as like Mulamba (2009). Ogbokor (2015) studies the dynamic relationship between government expenditure and economic growth in Namibia utilizing the two-step Engle-Granger approach.

In the Nepalese context, Shrestha (2009) determines the effect of the various components of public expenditure on the economic growth of Nepal. It has used the time series model with the application of the endogenous growth model to measure the effect of the public expenditure on the different headings in the economic growth of Nepal. Physical infrastructure plays a very important role to enhance economic growth by promoting private market production. Sharma (2013) finds the trend and pattern of public expenditure and its effect on the economic growth of Nepal. The major findings of the research are share of development expenditure over total expenditure is decreasing over time, the share of current expenditure over total expenditure is increasing over time and there is a very low correlation between the government expenditure and economic growth in Nepal. Aryal (2011) finds are the public expenditure on the GDP is increasing over time, the share of current expenditure in the total expenditure is higher than the capital expenditure on the total expenditure and there is not any significant relationship between the public expenditure and economic growth for 23 years sample size. Rana (1988) analyzes the trend of revenue, expenditure, and the budget deficit in the Nepalese economy from 1964/65 to $1986 / 87$. The descriptive analysis reveals the increasing trend of revenue and expenditure. The trend of increasing regular and development expenditure has created a continuous deficit that has compelled the government to rely excessively upon foreign aid. Finally, it is found that the budget deficit is also increasing over time. Upreti (2002) explores the trend and pattern of the public expenditure and the growth rate of the development expenditure is decreasing over time but the growth rate of the recurrent expenditure is increasing. Kanel (1988) examines the growth, pattern, and impact of public expenditure on the economic growth of Nepal from 1965 
to 1981. It has used simple the OLS technique and institutes that the elasticity coefficient for total development expenditure, economic services, and social services concerning per capita income is more than unity to GDP. The growth of public expenditure is more stepper after only after 1970, and it grows faster than the recurrent expenditure.

Basnet (1983) finds out the trend of the public expenditure and resource gap. It has used the data set from 1964/65 to 1980/81. It has used descriptive analysis to achieve the objective of the research. The major conclusion of the research is the growth rate of the regular expenditure is higher than the growth rate of the development expenditure, the growth rate of total government expenditure is higher than the growth rate of the total government revenue and there was an increasing trend in the budget deficit. Bhusal (2014) excavates the Wagnerian hypothesis in the Nepalese economy, to check the causality between economic growth and government spending and to check the long-run relationship between them. The research used the data set from 1975 to 2012. Johanson cointegration test and error correction model (ECM) findings: there exists both the short run and the long-run relationship between the government spending and economic growth in Nepal, and the Wagnerian hypothesis do not exist in Nepalese economy. Granger causality test shows that government spending Granger causes economic growth but economic growth does not Granger causes government spending.

After the extensive review of empirical studies, it is analyzed that the raised issues of the paper are partially revealed, and there is a need to be addressed to the remaining research problem. Most of the national literature, for instance, Basnet (1983), Rana (1988), Kanel (1988), Upreti (2002), Aryal (2011), and Sharma (2013) are concerned to explore the descriptive analysis only. For example, share growth rate, trend, and pattern of public expenditure and income of Nepal. Nonetheless, Bhusal (2014) established closer research to this study, but the impact of real interest rate on income is the new investigation of this paper. This paper also unveils some other control variables along with government expenditure and real interest, which are average rainfall and trade openness. Therefore, its scope significant than the previous studies.

\section{Data and Research Methods}

The research caries only quantitative data. It follows the time series distribution from 1975-2015. The data are utilized from various sources published by government buddies of Nepal. Gross domestic product and government expenditure are hired from the various volumes of the economic survey, Ministry of Finance (MoF), Nepal. Similarly, import and export items are taken from industrial statistics, the Department of Customs, Nepal. The interest rate is sourced from Nepal Rastra Bank, and the average rainfall is abstracted from the department of hydrology and meteorology, Tribhuvan University. In the study, Real GDP is used as the proxy for the growth rate of income. Average annual rainfall is assumed positively with agricultural productivity. Trade openness is the sum of import and export volume as the percentage of GDP. Government expenditure is the total expenditure made by the government on recurrent and capital expenditure titles. National Income of Nepal highly depends on these variables. Therefore, it is worthwhile to select them for further analysis. 
46 | The Economic Journal of Nepal (Issue No. 150)

Table 1: Description of the Variable

\begin{tabular}{|l|l|}
\hline \multicolumn{1}{|c|}{ Variables } & \multicolumn{1}{c|}{ Sources } \\
\hline Real Gross Domestic Product (RGDP) & Various Issues of Economic Survey \\
\hline Real Government Expenditure (RGE) & Various Issues of Economic Survey \\
\hline Trade Openness (TO) & Department of Customs, Nepal \\
\hline $\begin{array}{l}\text { Average Rainfall (RF)= Average annual rainfall, collected } \\
\text { from 20 districts of Nepal }\end{array}$ & $\begin{array}{l}\text { Department of Hydrology and } \\
\text { Meteorology, TU }\end{array}$ \\
\hline Real Interest rate ( & Nepal Rastra Bank \\
\hline
\end{tabular}

\section{Model Specification}

The model is primarily concerned with the distribution of explained and explanatory variables. The dependent variable is real income (RGDP), and explanatory variables arereal government (RGE) expenditure, real interest rate 0 , average rainfall (RF), and trade openness (TO). Gujrati et al. (2012) distribute very lucid functional form in equation 1.0 followed by the linear model in equation 1.1 .

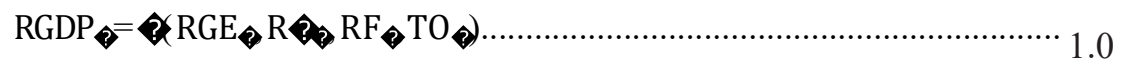

where, $\mathrm{t}=1975-2018$

The specification of equation 1.0 is converted into following semi-log linear extension:

$\ln \mathrm{RGDP}_{\mathrm{t}}=\psi+\beta \operatorname{lnRGE} \mathrm{t}_{\mathrm{t}}+\beta_{2} \operatorname{lndln}+\beta_{3} \mathrm{tnRi}_{\mathrm{t}}+\beta_{4} \ln \mathrm{TO}_{\mathrm{t}}+$ error $_{\mathrm{t}}$

where, $\psi$ is the arbitrary constant and $\beta_{14}$ are the regression coefficients.

\section{Unit Root Test}

Time-series data is said to be stationary if its mean and variance are constant over time and the value of the covariance between the two-time periods depends only on the distance or gap or lag between the two time periods and not the actual time at which the covariance is computed. If the time series data is not stationary there is the problem of spurious regression (Gujarati et al., 2012). Thus, before performing any kind of test or the model it is necessary to find out whether the data are stationary or not and that can be done by using the unit root test (Maddala, 2009).

Amid the various method of testing the unit root testing, this paper uses the Augmented

Dickey-Fuller (ADF) test. Gujarati et al., (2012) hint to expand the ADF equation as given in the equations (2.0) and (2.1), where, the symbol $\Delta$ indicates the first difference of the series. The equation (2.0) and (2.1) show the intercept and a time trend respectively, 
and $\mathrm{k}$ is the number of lagged variables that are used to ensure the error term e is white noise. The optimal number of lags selection criteria is the Akaike Information Criterion (AIC).

$$
\begin{aligned}
& k
\end{aligned}
$$

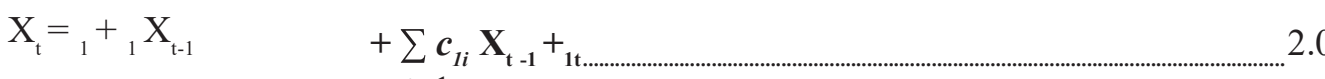

$$
\begin{aligned}
& i=1 \\
& \mathrm{X}_{\mathrm{t}}={ }_{2}+{ }_{2} \mathrm{X}_{\mathrm{t}-1}+\quad+\sum_{i} \mathrm{X}_{\mathrm{t}-1}+ \\
& =1
\end{aligned}
$$

The ADF techniques test the null hypothesis: $\gamma_{i}=0$, against the alternative hypothesis: $\gamma_{i}<$ 0 . Rejection of the null hypothesis is an indication that the series $X_{t}$ is stationary. In equation (2.0) the alternative hypothesis indicates the series is a mean-stationary and in equation (2.1) it indicates the series is trend stationary.

\section{Autoregressive Distributed Lag Model (ARDL) to Cointegration Analysis}

One of the approaches to check the cointegration among the variables is the ARDL bound test. It is introduced by Pesaran and Shin (1999), and Pesaran, Shin, and Smith (2001). This test has several advantages over the well-known residual-based approach proposed by Engle and Granger (1987) and the maximum likelihood-based approach proposed by Johansen and Julius (1990), and Johansen (1992).

\section{Estimation of the Long Run Estimates of the Selected ARDL Model}

If a long-run relationship exists between the underlying variables, while the hypothesis of no long-run relations between the variables in the other equations cannot be rejected, then the ARDL approach to cointegration can be applied (Pesaran and Shin, 1999). To select the appropriate model of the long run underlying equation, it is necessary to determine the optimum lag length $(\mathrm{k})$ by using proper model order selection criteria such as; the Akaike Information Criterion (AIC) or Schwarz Bayesian Criterion (SBC). The selected ARDL (k) model long-run equation;

$$
\begin{aligned}
& \mathrm{Yt}=\delta 0+\sum \alpha 1 \mathrm{X} 1 \mathrm{t}+\sum \alpha 2 \mathrm{X} 2 \mathrm{t}+\sum \alpha 3 \mathrm{X} 3 \mathrm{t}+\sum \alpha \mathrm{Xnt}+v 1 \mathrm{t} \\
& \mathrm{i}=1 \mathrm{i}=1 \mathrm{i}=1 \mathrm{i}=1
\end{aligned}
$$

$\mathrm{S}(1,2$, n ) are the explanatory or the long run forcing variables, and $\mathrm{k}$ is the number of optimum lag order.

\section{Estimation of Co-integration and ECM}

Even if $Y_{t}$ and $X_{t}$ variables are cointegrated that means they have a long-run relationship, but there may be possibility disequilibrium in the short run. The Granger representation theorem says that if two variables $\mathrm{Y}_{\mathrm{t}}$ and $\mathrm{X}_{\mathrm{t}}$ are cointegrated, then the relationship between the two can be expressed as Error Correction Modeling as: 
48 | The Economic Journal of Nepal (Issue No. 150)

The ARDL (p, q1,q2..... qk) model approach to Cointegration testing;

$$
\begin{aligned}
& \text { K } \quad K
\end{aligned}
$$

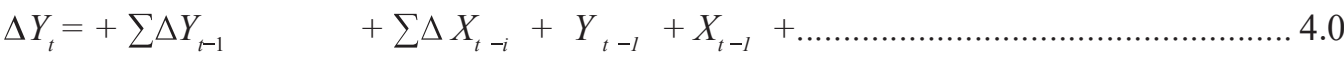

$$
\begin{aligned}
& i=1 \quad i=1
\end{aligned}
$$

$\mathrm{k}$ is the ARDL model maximum lag order and chosen by the user. The F-statistic is carried out on the joint null hypothesis that the coefficients of the lagged variables $\left(Y_{t-1}\right.$ or, $\left.X_{t-1}\right)$ are zero. - correspond to the long-run relationship, while- represents the short-run dynamics of the model.

The null of the non-existence of the long-run relationship is defined by;

Ho: $\delta 1=\delta 2=0$ (null, i.e. the long run relationship does not exist)

$\mathrm{H} 1: \delta 1 \neq \delta 2 \neq 0$ (Alternative, i.e. the long-run relationship exists)

This is tested in each of the models as specified by the number of variables.

This can also be denoted as follows:

$$
F y(Y 1 \mid X 1, \ldots, X k) \text {. }
$$

The hypothesis is tested employing the F- statistic (Wald test) in equation 4.1 and 4.0, respectively. The distribution of this F-statistics is non-standard, irrespective of whether the variables in the system are I(0) or I(1). The critical values of the F-statistics for the different number of variables $(\mathrm{K})$, and whether the ARDL model contains an intercept and/or trend are available Pesaran et al. (2001). They give two sets of critical values. One set assuming that all the variables are $\mathrm{I}(0)$ (i.e. lower critical bound which assumes all the variables are $\mathrm{I}(0)$, meaning that there is no cointegration among the underlying variables) and another assuming that all the variables in the ARDL model are I(1)( i.e. upper critical bound which assumes all the variables are I(1), meaning that there is cointegration among the underlying variables).

The best-performed model provides the estimates of the associated Error Correction Model (ECM).

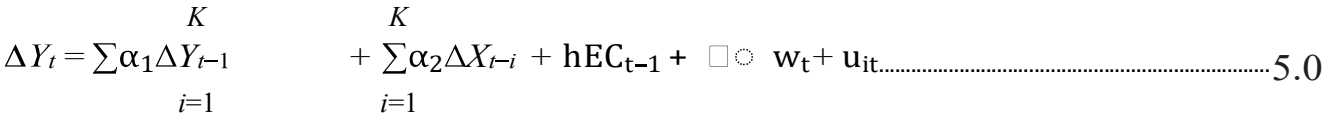

$$
\begin{aligned}
& \text { Where, } \mathrm{EC}_{\mathrm{t}}=\mathrm{Yt}
\end{aligned}
$$

$\mathrm{EC}_{\mathrm{t}}$ is the residuals that are obtained from the estimated cointegration model of equations 4.6. The term $\mathrm{EC}_{\mathrm{t}}$ as the speed of adjustment parameter or feedback effect is derived as the error term from the cointegration models (4.0), whose coefficients are obtained by normalizing 
the equation on $X_{t}(4.0)$. The $\mathrm{EC}_{\mathrm{t}}$ shows how much of the disequilibrium is being corrected, that is, the extent to which any disequilibrium in the previous period is being adjusted in $Y_{t}$. A positive coefficient indicates a divergence, while a negative coefficient indicates convergence. If the estimate of $\mathrm{EC}_{\mathrm{t}}=1$, then 100 percent of the adjustment takes place within the period, or the adjustment is instantaneous and full, if the estimate of $\mathrm{EC}_{\mathrm{t}}=0.5$, then 50 percent of the adjustment takes place each period/year. $\mathrm{EC}_{\mathrm{t}}=0$, shows that there is no adjustment, and to claim that there is a long-run relationship does not make sense anymore.

\section{Causality Test}

The Granger (1969) approach to the question of whether X causes $\mathrm{Y}$ is to see how much of the current $\mathrm{Y}$ can be explained by past values of $\mathrm{Y}$ and then to see whether adding lagged values of $X$ can improve the explanation. $Y$ is said to be Granger-caused by $X$ if $X$ helps in the prediction of Y. or equivalently if the coefficients on the lagged X's are statistically significant. Note that two-way causation is frequently the case; X Granger causes Y and Y Granger cause $\mathrm{X}$. Let see the basic format of Granger causality in bivariate regressions as the following way:

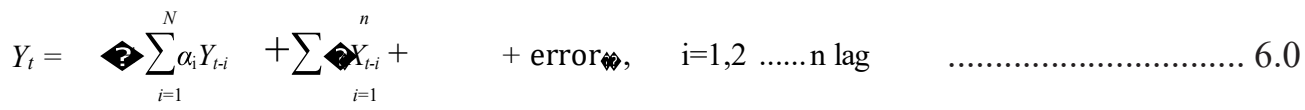

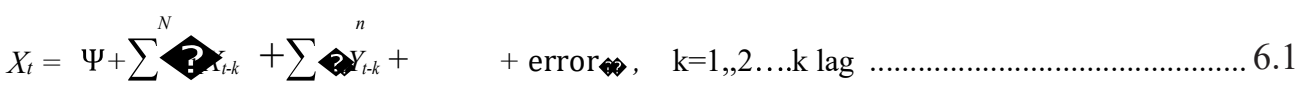

For all possible pairs of (X, Y) series in the group. The reported F-statistics are the Wald statistics for the joint hypothesis:

$$
\begin{aligned}
& H_{0}: 8_{i}=0 \text { or } X \text { does not Granger cause on } Y \text {. } \\
& H_{1}: 8_{i} G 0 \text { or } X \text { does Granger cause on } Y \text {, for equation } 6.0 \text {., or } \\
& H_{0}: p_{k}=0 \text { or } Y \text { does not Granger cause on } X \text {. } \\
& H_{1}: p_{k} G 0 \text { or } Y \text { does Granger cause on } X \text {, for equation } 6.1 \text {. }
\end{aligned}
$$

\section{Empirical Result and Discussion}

Table 2 shows the result of the ADF test of the concerned variables that are used in the study. The variables are found significant at their level that variables are presented as I (0), and the variables are found significant at their first difference are known as I (1). In the above figure, the only lnRF is found stationary in the level form. Similarly, $\ln R G D P, \operatorname{lnRGE}$, and are found to be stationary at first difference. All the variables are significant at less than 5 percent level of significance. Thus, Pesaran et al. (2001) suggest applying the ARDL co-integration technique for further processing.

Table 3 shows the result of the estimated long-run equilibrium of the model. The variableslnRGE, $\operatorname{lnRF}$ and TO have a positive relationship with $\operatorname{lnRGDP}$ and both $\ln R G E$ and TO are significant at less than 1percent level of significance, but $\ln R F$ is not significant. But, $R$ has a negative relationship with $\ln R G D P$ and it is significant with less than 10 percent level of significance. 
50 | The Economic Journal of Nepal (Issue No. 150)

Table 2: Result of ADF Test

\begin{tabular}{|l|l|l|l|l|l|}
\hline \multirow{2}{*}{ Variables } & \multicolumn{2}{|c|}{ Level } & \multicolumn{2}{c|}{ First Difference } & \multirow{2}{*}{ Remarks } \\
\cline { 2 - 6 } & Intercept & $\begin{array}{c}\text { Intercept and } \\
\text { Trend }\end{array}$ & \multicolumn{1}{|c|}{ Intercept } & $\begin{array}{c}\text { Intercept and } \\
\text { Trend }\end{array}$ & R. \\
\hline InRGDP & $0.291(0.60)$ & $1.492(0.526)$ & $6.333(0.00)$ & $6.247(0.000)$ & I (1) \\
\hline InRGE & $1.346(0.936)$ & $3.391(0.526)$ & $6.268 * 0.009)$ & $6.090^{*}(0.0007)$ & I (1) \\
\hline InRF & $5.380(0.012)$ & $5.325(0.005)$ & & & I (0) \\
\hline Ri & $1.1604(0.938)$ & $0.38(0.529)$ & $3.8651^{*}(0.001)$ & $3.8668(0.000))$ & I (1) \\
\hline TO & $2.007(0.950)$ & $0.714(0.523)$ & $3.9807(0.000)$ & $4.112(0.000)$ & I (1) \\
\hline
\end{tabular}

Source: Authors' calculation

The econometrical interpretation of these results is: per one percent increase of real government expenditure and trade openness leads to an increase of 0.41 and 0.34 percent on an average respectively. Similarly, per one percent increment of the real interest rate significantly reduces the real income by 0.1154 percent. The real interest has a duel effect on the household sector and the business sector at the same time. If real interest falls, it increases private investment.

Table 3: Estimation of the Long Run Estimates

\begin{tabular}{|l|c|c|c|c|}
\hline \multicolumn{5}{|c|}{ Dependent Variable: LNRGDP } \\
\hline Repressors & Coefficient & Standard Error & t-ratio & p-value \\
\hline InRGE & $0.4150^{*}$ & 0.0494 & 12.4333 & 0.0000 \\
\hline InRF & 0.3392 & 0.2503 & 1.3550 & 0.1859 \\
\hline TO & $0.3339^{*}$ & 0.1023 & 3.2620 & 0.0028 \\
\hline Ri & $-0.1154^{* *}$ & 0.0633 & -1.8230 & 0.0786 \\
\hline C & 1.4200 & 0.8993 & 1.5790 & 0.1252 \\
\hline
\end{tabular}

Source: Authors' calculation

On the other hand, if the real interest rate increases, it induces savings by cutting the present consumption expenditure for future income; this called the substitution effect. If most of the people are doing this, aggregate consumption becomes lower and it re insults the negative impact on the domestic output at the current time. Chaudhary (2017) also reveals two premises regarding it: First, consumption to GDP ratio is almost greater than 80 percent over a long period in Nepal; second, there is the presence of substitution effect in Nepalese consumer behavior. Therefore the estimated result of the real interest rate is desirable in the long run. With the increase in the total trade, there are different opportunities in the country that helps to increase employment and ultimately increases the aggregate demand for goods and services and contribute to the GDP. Rainfall has not recorded long-run effects. 
Table 4: Estimation of ARDL Cointegration

\begin{tabular}{|c|c|c|c|}
\hline F- statistics & Lower Bound & Upper Bound & Level of Significance \\
\hline 26.2424 & 3.29 & 4.37 & 1 percent \\
\hline & 2.56 & 3.49 & 5 percent \\
\hline & 2.2 & 3.09 & 10 percent \\
\hline
\end{tabular}

Source: Author's calculation

Table 4 is the estimated result of the co-integration test. Here, calculated F-statistics is 26.2424, which is higher than both the lower bound and upper bound values in the defined (1, $5, \& 10$ percent) level of significance. This shows the rejection of the null hypothesis that is "there is no long-run relationship among the variables". In other words, there is an established long-run relationship among the variables or the concerned variables are co-integrated.

Table 5 analyzes error correction or the short-run dynamics of the selected ARDL model. The coefficient of the error correction term is negative and statistically significant. It indicates the speed of adjustment for the model.

Table 5: Short Run Dynamics of the Model $(1,1,1,1,0)$

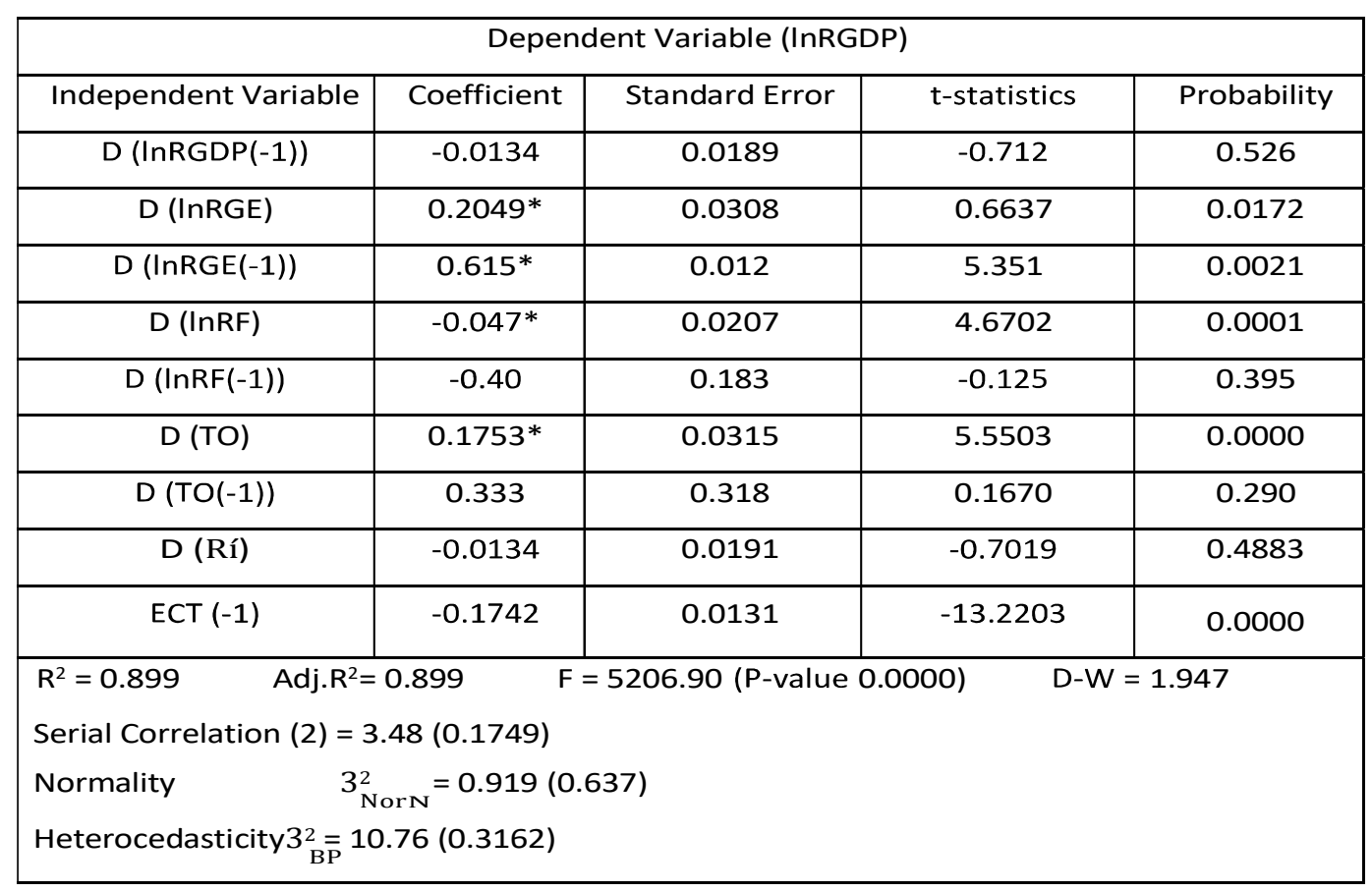

Source: Authors' calculation 
52 | The Economic Journal of Nepal (Issue No. 150)

It is affirmed as 17.42 percent at less than 1 percent significance level. The lower value of the error correction term implies the slow rate of the adjustment when shocks arise. For instance, the model shows that the rate of adjustment for equilibrium is 17.42 percent per annum. Furthermore, it can be seen that the difference of $\operatorname{lnRGE}$, lnRF, and TO has a positive relationship with lnRGDP and all of them are significant at 1 percent level of significance. Every 1 percent increase in D (TO) causes to increase in the difference of $\operatorname{lnRGDP}$ by 0.20 and 0.17 percent respectively. $\mathrm{D}(\mathrm{lnRF})$ has a negative coefficient $(-0.047)$ to the real GDP and it is statistically significant.

These findings have a serious interpretation of economics. Increasing or decreasing government expenditures a multiplier effect in income in the short run too. An inducement of government expenditure the real GDP by government expenditure multiplier in the economy. Government final expenditure comes in the form of recurrent, capital, and transfer payment in the circular flow of the economy. In the short-run analysis, government expenditure has found a significant one lag to its current GDP growth. In the same way, average rainfall has significant result in the short-run, however, in the long-run, it is reported insignificant. The current rainfall determines to produce the current agricultural output for Nepal. Nepalese agriculture highly depends on monsoon. Therefore, the reported coefficient is very practical. One percent increment in average rainfall leads to an increase of 0.09 percent agriculture GDP on average. Navaya (2011) reveals that 80 annual precipitation occurs between June and September and mainly it affects production, where rice is the topmost output among all. Regarding this, if the monsoonal rai ng is excess supplied it may reduce the rice production instead of higher yield. Increasing trade openness implies increase the trade volume of the country and that helps to create employment opportunities. It increases the aggregate demand and hence increases in GDP of the country.

Figure1: Cumulative Sum of Recursive Residuals (CUSUM) Test

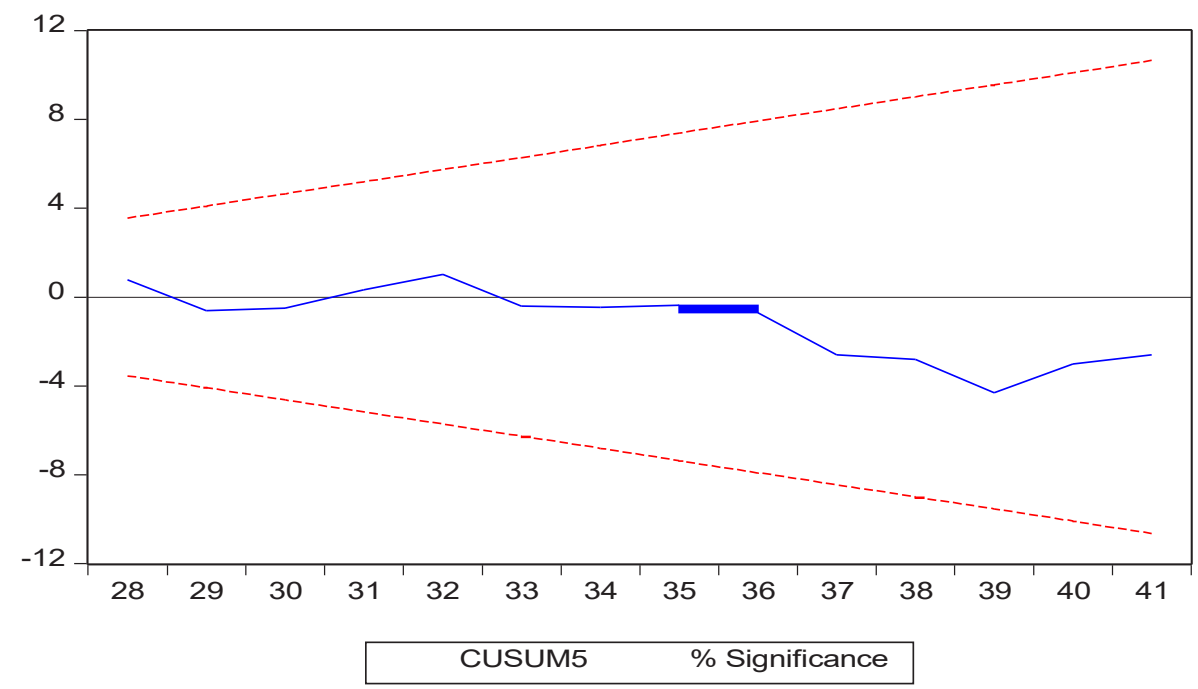

Source: Author's calculation 
Figure 2: Cumulative Sum of Square of Recursive Residuals

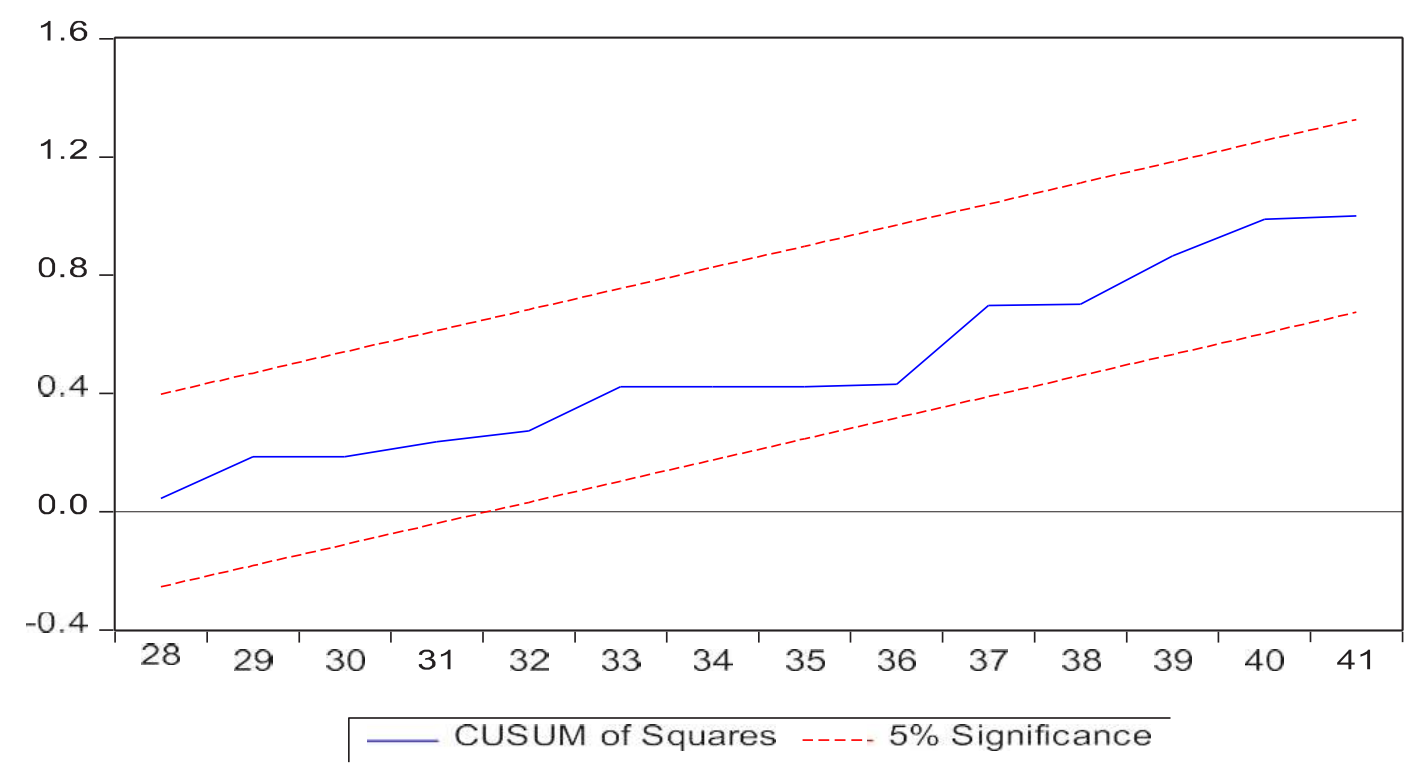

Source: Author's Calculation

The estimated models are free from serial correlation, homoscedastic but not normally distributed. Cumulative Sum of Recursive Residuals (CUSUM) and Cumulative Sum of Squares of Recursive Residuals (CUSUMSQ) tests proposed by Borensztein et al. (1998) show that the long-run parameters with short-run movements for the estimated equations are stable.

\section{Causal Relationship between Public Expenditure and Economic Growth}

Pairwise Granger Causality test has been used to check the causality between public expenditure and economic growth. Since both variables RGE and RGDP are I (1) variable so, the causality can be checked only in the first difference of both variables. This study has chosen the Schwarz criterion for the causality station.

Table 6: Results of the Pairwise Granger Causality Test

\begin{tabular}{|l|c|c|c|}
\hline Sample: $1975-2018$ & F-statistics & Probability & Decision \\
\hline Lags: 1 & & & \\
\hline Null Hypothesis & & & \\
\hline InRGDP does not Granger cause InRGE & $3.6596^{*}$ & 0.0364 & Rejected \\
\hline InRGE does not Granger cause InRGDP & $4.6919^{*}$ & 0.0159 & Rejected \\
\hline
\end{tabular}

Source: Authors' calculation 
54 | The Economic Journal of Nepal (Issue No. 150)

Table 6 shows the result of the Pairwise Granger causality test between government expenditure (lnRGE) and income (lnRGDP) with one lag. After the estimation, it is revealed that there is existed bidirectional causality between real government expenditure and real income. The obtained result is quite burnished than the findings of Bhusal (2014). The Fstatistics for both variables is significant at 5 percent level of significance.

\section{Conclusion}

Among the contentious arguments regarding government expenditure and economic growth, this paper carries some unique exposer of public expending and the real interest rate on the real income of Nepal for1975-2018. The study implies the ARDL cointegration technique. It observes the existing long-run relationship among the variables. It is also found that there is a positive and significant relationship subsisted between public expenditure and economic growth in the short-run and long-run equilibrium. Also, in the short-run analysis, there is found one lag effect of real government expenditure to real income.

Similarly, trade openness and rainfall have a positive and significant relationship with GDP in the short run. These both are short-run factors to boost the output of the economy. The real interest rate has a substitution effect on the Nepalese household sector, hence it hurts the real income in the long-run. However, the short-run equilibrium does not have this kind of relationship. The openness of trade has a positive and significant relationship with GDP in the long run. This is a very obvious result. Increasing the share of total trade. The speed of adjustment parameter, the error correction term, is reported 17.42 percent per annum to achieve equilibrium after any shocks arise.

The study also concludes the existence of the bidirectional causal relationship between government expenditure and real income. Policymakers should be focused on increasing government expenditure that helps to increase economic growth. Increasing openness of trade also helps to increase the GDP of the country by increasing the income and employment opportunity in the country. It is better to increase the export than in the import. The government should focus on the building of the long term irrigation projects for the farmers that help to decrease the dependency of rainfall and ultimately increases the agricultural GDP.

\section{References}

Ahuja, H. L. (2011). Macroeconomics theory and policy (1 $1^{\text {th }}$ ed.). New Delhi: S. Chand and Company Ltd.

Alexiou, C. (2009). Government spending and economic growth: Economic evidence from south Eastern Europe. Journal of Economic and Social Research, 11(1): 1-16.

Alshahrani, S., \& Alsadiq, A. J. (2014). Economic growth and government spending in Saudi Arabia: An empirical investigation. IMF Working Paper No.1403.

Aryal, T. K. (2011). The relationship between public expenditure and economic growth. Unpublished master's thesis in economics. Central Department of Economics, 
Tribhuvan University, Kirtipur, Kathmandu.

Basnet, D.B. (1983). Analysis of public expenditure and economic development in Nepal. (Unpublished master's thesis in economics. Central Department of Economics, Tribhuvan University, Kirtipur, Kathmandu.

Baumol, W. J. (1986). Productivity growth, convergence, and welfare: What the long-run data show. American Economic Review, 76(5): 1072-1085.

Bhusal, T. P. (2014). Government spending and economic growth in Nepal. Nepalese Journal of Economic Studies, 1(1):52-61.

Bleaney, M., Gemmell, N., \& Kneller, R. (2000). Testing the endogenous growth model: American Behavioral Scientist, 20(5): 635-642.

Chaudhary, A. (2017). Estimation of aggregate consumption function for Nepal: ARDL bound testing approach. NRB Economic Review, 29 (2): 51-65.

Desmond, N. I., Titus, O. A., Timothy, O., \& Odiche, N. L. (2012). Effects of public expenditure and economic growth. An empirical examination of the Greek Economy. Working Paper No. 67.

Goode, R. (1984). Government finance in developing countries. New Delhi: McGraw-Hill Publishing House Ltd.

Granger, C. W. J. (1969). Investigating causal relations by econometric models and crossspectral methods. Econometrica, 37 (3): 424-438.

Gujarati, D. N., Porter, D. C., \& Gunasanker, S. (2012). Basic econometrics (5th ed.). New Delhi: McGraw Hill Education Private Limited.

Hidayat, A., \& Suman, S. (2012). The effect of inflation, interest rates, and government expenditure in Indonesia: A cointegration analysis. Jakau Econ \& Admin, 24(1): 199-209.

Hidayat, A., \& Suman, H. (2012). The composition of public expenditure and economic growth. Journal of Monetary Economics, 37: 313-344.

Johansen, S. (1992). Co-integration in partial systems and the efficiency of single-equation analysis. Journal of Econometrics, 52 (3):389-402.

Johansen, S., \& Julius, K. (1990). Maximum likelihood estimation and inference on cointegration with application to the demand for money. Oxford Bulletin of Economics and Statistics, 52 (2):169-210.

Kanel, D. R. (1988). Public expenditure in Nepal: Growth, pattern, and impact. New Delhi: Sterling Publishers.

Keynes, J. M. (1936). The general theory of employment, interest, and money. Cambridge: Macmillan Cambridge University Press.

Kosimbei, G., Muthui, J. N., Maingi, J., \& Thuku, G. K. (2013). The impact of public 
56 | The Economic Journal of Nepal (Issue No. 150)

expenditure components on economic growth in Kenya 1964-2011. International Journal of Business and Social Science, 4(4): 123- 133.

Kweka, J. P., \& Morrissey, O. (1997). Government spending and economic growth in Tanzania, 1965-1996. United Kingdom: Centre for Research in Economic Development and International Trade, University Nottingham. Retrieved from https://www.nottingham. ac.uk/credit/documents/papers/00-06.pdf.

Maddala, G. (2009). Introduction to econometrics. New Delhi: Mc Graw Hill Publication.

Mankiw, N., Romer, D., \& Weil, D. (1992). A contribution to the empirics of economic growth. Quarterly Journal of Economics, 107(2): 407-437.

Mulamba, K. C. (2009). The long-run relationship between government expenditure and economic growth: Evidence from SADC countries (Unpublished master's thesis). Johannesburg: The Faculty of Economics and Financial Sciences, University of Johannesburg.

Musgrave, R. (1969). Fiscal systems. New Delhi: Yale University Press.

Nayava, J. (2017). Monsoonal rainfall and its impact on rice production in Nepal. Research Gate, Retrieved from https://www.researchgate.net/publication/326677819_ Monsoonal_rainfall_and_its_impact_on_rice_production_in_Nepal

Oyinlola, M. A., \& Akinnibosun, O. (2013). Public expenditure and economic growth nexus: Further evidence from Nigeria. Journal of Economics and International Finance, 5(4): 146-154.

Peacock, A., \& Wiseman, J. (1961). The growth of public expenditure in the United Kingdom. National Bureau of Economic Research, 5(3): 1-32.

Pesaran, M. H., \& Shin, Y. (1999). An autoregressive distributed lag modeling approach to co-integration analysis. Econometric Society Monographs, 31:371- 413.

Pesaran, M.H., Shin, Y., \& Smith, R. (2001). Bounds testing approaches to the analysis of level relationships. Journal of Applied Econometrics, 16 (3): 289-326.

Rahman, M. (2012). The relationship between economic growth and government expenditure: evidence from Sudan. International Business Research, 5(8):87-98.

Rahn, R., \& Fox, H. (1996). What is the optimum size of government? Colorado USA: Vernon K. Krieble Foundation.

Rana, D.S. (1988). The fiscal system of Nepal. Unpublished master's thesis in economics. Central Department of Economics, Tribhuvan University, Kirtipur, Kathmandu.

Romanus, M. (2014). The effect of public expenditure on economic growth: Turkey. Investment Management and Financial Innovations, 9(2): 302-315.

Rostow, W.W. (1971). Politics and stages of growth. United Kingdom: Cambridge University Press. 
Saymeh, H, \& M. Orabi (2013). The effect of interest rate, inflation rate on real economic growth in Jordan. Asian Economic and Financial Review, 3(3): 341-354.

Saymeh, R., \& Orabi. S. (2013). Determinants of economic growth (The expert's view). Discussion Paper Series, 15(1):1-22.

Shapiro, E. (2001). Macroeconomic analysis ( $5^{\text {th }} e d$.). New Delhi: Galgotia Publication.

Sharma, V. P. (1999). The problem and prospects of the regular and development budget of HMG Nepal. The Economic Journal of Nepal. 5(3): 1-32.

Shrestha, P. K. (2009). The composition of public expenditure, physical infrastructure, and economic growth in Nepal. NRB Economic Review, 21:1-4

Udoka, E., \& Roland, S. (2013). The effect of interest rate variability on the economic growth of Nigeria. Unpublished Ph.D. thesis. Department of Economics and Development Studies, Covenant University, Nigeria.

Udoka. C. \& Roland, J. (2012). Interest rate variation and investment determination in Nigeria. International Business Management, 4(2): 41-46.

Upetri, B. (2002). A study on the performance of public expenditure in Nepal. The Economic Journal of Nepal, 8 (2):20-31.

Weber, M. (1947). The theory of economic and social organization. New York: Henderson and Talcott Parsons. 